\title{
An Evaluation of Abidjan Container Terminal Competitive Position in West Africa Using a Fuzzy Quantified SWOT Framework
}

\author{
China Flora Carine Anguibi', Veronique Nguele Balla², Brou Mathias Allate1 \\ ${ }^{1}$ School of Economics and Management, Shanghai Maritime University, Shanghai, China \\ ${ }^{2}$ Scientific Research Academy, Shanghai Maritime University, Shanghai, China \\ Email: anguibicarine@hotmail.com,v.ballanguele@gmail.com, abromat@yahoo.fr
}

How to cite this paper: Anguibi, C.F.C., Balla, V.N. and Allate, B.M. (2016) An Evaluation of Abidjan Container Terminal Competitive Position in West Africa Using a Fuzzy Quantified SWOT Framework. Open Journal of Applied Sciences, 6, 648-666.

http://dx.doi.org/10.4236/ojapps.2016.69062

Received: August 17, 2016

Accepted: September 20, 2016

Published: September 23, 2016

Copyright (c) 2016 by authors and Scientific Research Publishing Inc. This work is licensed under the Creative Commons Attribution International License (CC BY 4.0).

http://creativecommons.org/licenses/by/4.0/

\begin{abstract}
This article proposes a quantified SWOT framework which integrates fuzzy linguistic preference relation to evaluate the competitive position of Abidjan container terminal in West Africa. The integration of fuzzy linguistic preference relation in the quantified SWOT framework circumvents the difficulties in terms of data collection and consistency of judgment matrices prevailing in the conventional AHP and Fuzzy AHP. Moreover, the study provides relevant evidences about the key internal and external attributes shipping lines considered as important and hence the attributes that ports/ terminals most need to enhance in order to improve their attractiveness and be well positioned in the market. On the other hand, the change in terminals competitive position between 2010 and 2013 highlights that the difficulties of West African ports in attracting customers in the sub-region are not only related to internal problems such as inadequate infrastructures, facilities or inefficiency, but significant political and economic constraint outside the ports constraints their competitiveness.
\end{abstract}

\section{Keywords}

Port Competitiveness, Fuzzy Linguistic Preference Relation, SWOT, Port Selection Criterial, African Port

\section{Introduction}

Containerization and the ever-increasing size of ships have facilitated the movement and increased the volume of goods transported worldwide but also put more pressures on port authorities limited in their ability to expand easily and fast their infrastructures. Shipping companies looking for economies of scale, tend to concentrate on a limited 
number of ports capable of offering competitive services [1]. Hence, in order to avoid being marginalized in the business environment or lose their market shares, ports whether located in the developed or undeveloped countries, are forces to adopt measure aiming to enhance their operational efficiency, reduce the cost of their operation or upgrade their facilities. In the context of this competitive business environment, major coastal countries in West Africa, namely, Cote d'Ivoire, Ghana, Senegal, Nigeria, Benin, and Togo, have implemented some reforms aiming to build or upgrade their container terminal infrastructures and improve management practices in order to supply efficient services and promote the integration of the sub-region into the global market. With the rise of port development in the region, intense pressures in terms of competitiveness have been put on terminals and ports, especially Abidjan, one of the first and leading container terminals.

Abidjan, recovering from a decade of political crisis in Cote D'Ivoire, ended in 2011, faces greater challenges in terms of attractiveness that is keeping its existing customers and attracting new customers. The port suffers from the lack of terminal infrastructures and operations, fragile political environment and limited performance affecting import and export competitiveness. Moreover, the container terminal faces constant risk of losing its customers not just because of the factors mentioned, but also because of the changing and various requirements of customers. Accordingly, in this complex and competitive environment, making the right strategic decision aiming to serve the interest of their clients is essential for Abidjan to succeed in West African maritime market. Furthermore, in order to develop or maintain a superior position in the market over its competitors, the container terminal should understand the factors affecting its main customers' decision that is shipping lines decision to call at a specific port. It is worth mentioning that shipping lines make port selection decisions by considering port internal and external environmental factors [2]. A misunderstanding of these factors can lead the container terminal to a waste of resources and failure.

The analysis of the internal and external environmental condition of ports considering the factors influencing the decision making process of port users allows a better understanding of factors determining port attractiveness and thus competitiveness. Moreover, it can serve as a basis to what can, and cannot be done to improve particularly the competitive position of port. According to scholars [3] [4], the analysis of organization's strength, weakness, opportunities and threat (SWOT) is one of the powerful tools used in the adoption of strategy. SWOT analysis is a strategic management tool employed to formulate strategy based on the evaluation of strength and weakness within the organization and opportunities and threat that are outside the organization. However, the conventional SWOT analysis is a literal description rather than quantified analysis and as such is insufficient [5]. For instance, the conventional SWOT does not provide an analytical mean to prioritize factors and strategies and to determine the relative importance of factors in the multi-criteria analysis [3]. In order to solve this drawback and enhances the subjective analysis inherent to SWOT many researchers have proposed a hybrid SWOT approach. Researchers [3] in order to prioritize strate- 
gies in Foreign Exchange market in Iran, proposed a hybrid method combining SWOT and SEM (structural equation Modelling) method. The Analytic hierarchy process (AHP) technique developed by [6] has been integrated to SWOT analysis to assess the weight of the SWOT factors [7]. Nevertheless, unlike the conventional SWOT and the others hybrid method based on SWOT, the quantified method proposed by researchers [5], rather than just providing an analytical mean to either determine the weight of the factors or prioritize factors or strategies for organization, offers a framework to carry out SWOT comparison on several enterprises simultaneously. The authors developed a hybrid AHP SWOT method based on the grand strategy matrix (GSM) model, to assess the competitive position of container ports in East Asia. The analytical technique not only offers a framework to identify the competitive position of firms but also provides a reference for formulating strategies in accordance with the GSM model [8]. In other terms, using the quantified method, the competitive position of the organizations evaluated can be identified and serve as a basis to formulate strategies. This method has been applied by others researchers in maritime sector and in software industry, demonstrating the applicability and the usefulness of the model in strategy formulation in the competitive environment. For instance, scholars [8] employed the quantified methodology but integrated Fuzzy AHP to SWOT analysis instead of using the conventional AHP, to assess the competitive environment of international distribution centers in $\mathrm{Pa}$ cific-Asian region. In the same vein, the quantified SWOT integrating fuzzy AHP was used by [9] to assess the competitive strength of software companies in China. The authors have indicated that integrating fuzzy theory in the conventional AHP when using the quantified SWOT approach contributes to reduce the fuzziness existing in many decision making problems.

Fuzzy AHP method allows the estimation of the weights of attributes and the priorities of alternatives from the pair wise comparison matrices considering the fuzziness in human perception when making decision. However, in practice, some researchers have revealed that the methodology has some drawbacks. For instance, fuzzy AHP technique can lead to great difficulties and challenges in the collection of data [10]-[13]. The authors have stressed that the conventional fuzzy AHP can be time consuming in case of an increased numbers of data and can lead to inconsistent results. Consequently, to overcome its limitations, the fuzzy linguistic preference relation approach was constructed in [10] based on the consistent fuzzy preference relations (CFPRs) developed by [14] and later applied in the work of [11]-[13]. The technique reduces the number of pair wise comparison in the conventional AHP from $n(n-1)$ to $(n-1)$ and produces consistent results. However, to the best of our knowledge, a study integrating fuzzy linguistic preference relation to SWOT method has not been found in the literature. Against this background, this research suggests a quantified SWOT method which integrates the fuzzy linguistic preference relation to evaluate the competitive position of major container terminals in West Africa sub-region. The remainder of this study is structured in following ways: Section 2 presents the literature review; Section 3 describes the research methodology; Section 4 presents and discusses the results. The study ends with a conclusion in Section 5. 


\section{Review of Factors Affecting Port Selection}

The review of the studies related to port choice criteria provides substantial information about the key findings in different geographical area. Furthermore, the review of the literature shows that past studies investigating the determinants of port competitiveness consider the factors that are important to port users when choosing a port of call. In others terms, these studies have focused on port selection criteria. A number of studies on port selection criteria have used various methods revealing varying factors affecting the perception of shipping lines in their decision to call at a specific port. For instance, in the Western context, researchers [15] found that cost, hinterland connections, capacity, reliability, port location and cargo base had an influence on port selection while customer service qualities, location in port, total door-to-door transport time and feeder frequency were of low importance. Another study conducted by [16] confirmed the importance of hinterland connections and cost from shipping lines perspective and identified immediacy of consumers and feeder connectivity as also key determinants. In the Asian context, amount of cargo loading and unloading and cost were the key factors affecting shipping liners' satisfaction for container terminal in the research conducted by [17]. Similarly an investigation by [18] identified that cost, hinterland condition are important from the perspective of shipping lines as in the studies conducted by [15] in the western context. Moreover, they indicated that port service, availability, convenience, logistics cost, regional centre and connectivity also influenced port competitiveness in the region. Researchers [19] determined that adequacy of port facilities, service flexibility in meeting customer's special needs, navigation costs and cargo handling costs and availability of information systems were the most important determinants of port choice whereas the study conducted by [20] revealed that local cargo volume, terminal handling charge, berth availability, port location, and transshipment volume and feeder network were key factors. A study by [21] highlighted that cost, customs and government regulation, hinterland connections and terminal by order of importance operators were significant attributes of port competitiveness. Conversely, shipping lines calling at West African ports pay much attention on port infrastructure, port draught, political stability, market size/cargo volume, and international networks respectively [22]. In South Africa, cargo profitability, draft, inland intermodal services, transshipment cargo volume, geographical location, berth availability and information technology ability have been found as having an influence on port choice decision [23]. Besides the factors mentioned above, some researchers identified some external variables affecting port competitiveness. For instance, scholars [24] demonstrated that in addition to port infrastructure endowment, factors such as corruption level, internet users, economy performance of port host country, liner shipping connectivity index and piracy attack may have an influence on port attractiveness and thus port competitive position. Furthermore, a research by [25] indicated that there is a positive relationship between container port competitiveness and the volume of traffic. According to the same researchers, container port competitiveness depends to their internal quality and external environments. 


\section{Port Environmental Condition}

There are various factors affecting port choice decision and thus port competitiveness. These factors can be categorized in two main groups, which are factors related to internal environment and factors from the external environment. The internal environment of port includes factors within port and under its control while the external environment encompasses factors related to competitors, suppliers, political conditions, and government regulations which are not controllable by the ports. The internal environment factors include resources and capabilities affecting port competitive position. The key challenges for ports in order to be competitive, is to develop effective facilities, supply reliable services at the competitive price, and achieve efficient productivity level. Accordingly, the internal resources can be related to port infrastructures and conditions of its facilities and equipment. Port infrastructures can be related to yard and warehouse potential capacity storage as well as berth capacity to accommodate different size of vessels. Regarding the facilities and equipment, availability and quality of handling equipment are considered by shipping lines in their decision to select a particular port. Besides, port capabilities refer to port security, information systems, service quality and efficiency. Efficiency can be reflected in ship turnaround time, crane productivity, dwell time and the volume of container handled revealing the current status of port in terms of handling ability but also its development potential. Moreover, service quality is associated with customers' satisfaction level. This implies that a shipping line will select the port meeting it expectation with regards to the level of service offer.

On the other side, the external factors influencing port competitiveness can be related to the locational advantage of port, political environment of port region and socio-economic development of port's hinterland and government policies and regulations regarding custom service. The locational advantage of port includes the proximity to hinterland and significance in the international shipping network. As pointed by [24], the higher the integration of port in the global shipping network, the higher its reputation in the industry which may increase its attractiveness and thus contribute to enhance its competitiveness. Moreover, in light to the weaknesses of the intermodal transportation in Africa due to poor conditions of road and rail transportation, the closer the port is to the hinterland, the higher is its attractiveness. A stable political environment of port region is one of the main factors affecting shipping line decision in choosing a port in West Africa [22]. Therefore, it influences on port competitiveness cannot be neglected. The efficiency of custom service in ports reflects in a great extent the policies and regulation adopted by the different government and may influence port performance. Furthermore, within a particular range, ports activities are influencing primary by the economy conditions and policies of port host country which include economic performance and trade liberalization.

\section{Research Methods}

\subsection{Fuzzy Linguistics Preference Relation Framework}

Based on the work of [14], the definition of a fuzzy preference relation is presented as 
follows:

A fuzzy preference relation $\mathrm{P}$ on a set of alternatives $X=\left\{x_{1}, x_{2}, \cdots, x_{n}\right\}$ is a fuzzy set on the product set $X \times X$ with membership function $P: X \times X \rightarrow[0,1]$. The preference relation is characterized by the $n \times n$ matrix $P=\left[p_{i j}\right]$, where $p_{i j}=\left(x_{i}, x_{j}\right)$ for all $i, j \in\{1, \cdots, n\}$. For $p_{i j}$ defined as the degree of preference of $x_{i}$ over $x_{j}$, if $p_{i j}=0.5$, it shows that no difference exists between $x_{i}$ and $x_{j}$ and $p_{i j}=1$ means that $x_{i}$ is absolutely preferred to $x_{j}$, and $p_{i j}>0.5$ implies that $x_{i}$ is preferred to $x_{j}$. In this case, the preference matrix $\mathrm{P}$ is assumed to be an additive reciprocal that is $p_{i j}+p_{j i}=1$ for all $i, j \in\{1,2, \cdots, n\}$. Due to the fact that, the consistency fuzzy relation defined above use crisp value in the fuzzy preference relation matrices and thus does not capture the fuzziness in human evaluation. Researchers [10] developed the fuzzy linguistic preference relation by integrating fuzzy linguistic assessment variables which are quantified by triangular fuzzy numbers (TFNs) in the decision matrices. The same scholars assume that if a given set of alternatives $X=\left\{x_{1}, x_{2}, \cdots, x_{n}\right\}$ associated with the fuzzy linguistic preference relations matrix $P=p_{i j}=\left(p_{i j}^{l}, p_{i j}^{m}, p_{i j}^{u}\right)$ with respect to $\mathrm{n}$ evaluation criteria $C=\left\{c_{1}, c_{2}, \cdots, c_{n}\right\}$ verifies the additive reciprocal consistency properties, then the following statements must be equivalent.

$$
\begin{aligned}
& p_{i j}^{l}+p_{j i}^{u}=1 \quad \forall i, j \in\{1, \cdots, n\}, \\
& p_{i j}^{m}+p_{j i}^{m}=1 \quad \forall i, j \in\{1, \cdots, n\}, \\
& p_{i j}^{u}+p_{j i}^{l}=1 \quad \forall i, j \in\{1, \cdots, n\}, \\
& p_{i j}^{l}+p_{j k}^{l}+p_{k i}^{u}=\frac{3}{2} \forall i<j<k, \\
& p_{i j}^{m}+p_{j k}^{m}+p_{k i}^{m}=\frac{3}{2} \forall i<j<k, \\
& p_{i j}^{u}+p_{j k}^{u}+p_{k i}^{l}=\frac{3}{2} \forall i<j<k, \\
& p_{i(i+1)}^{l}+p_{(i+1)(i+2)}^{l}+\cdots+p_{(j-1) j}^{l}+p_{j i}^{u}=\frac{j-i+1}{2} \quad \forall i<j, \\
& p_{i(i+1)}^{m}+p_{(i+1)(i+2)}^{m}+\cdots+p_{(j-1) j}^{m}+p_{j i}^{m}=\frac{j-i+1}{2} \quad \forall i<j, \\
& p_{i(i+1)}^{u}+p_{(i+1)(i+2)}^{u}+\cdots+p_{(j-1) j}^{u}+p_{j i}^{l}=\frac{j-i+1}{2} \quad \forall i<j .
\end{aligned}
$$

The statements presented in (1) are very important in the sense that they are used to construct the judgments matrices. Experts are invited to provide pair wise comparisons for a set of $n-1$ preference values. In others terms, they must fill the questionnaire by providing answer for only $n-1$ cells of the matrices and the values of the other cells are obtained by applying the statements in (1) in order to obtain an additive reciprocal consistency matrices. After construction of the preference matrices, in order to preserve the reciprocity and additive consistency, scholars [10] suggest to apply the function written below to transform the judgments values in case the pair wise comparisons matrices obtained, have values included in the interval $[-c, 1+c]$ rather than in the interval $[0,1]$. 


$$
\begin{aligned}
& f\left(x^{l}\right)=\frac{x^{l}+c}{1+2 c}, \\
& f\left(x^{m}\right)=\frac{x^{m}+c}{1+2 c}, \\
& f\left(x^{u}\right)=\frac{x^{u}+c}{1+2 c} .
\end{aligned}
$$

where $\mathrm{c}$ is the maximum amount of violation from interval $[0,1]$ among elements of $\mathrm{P}$.

Determination of Criteria Weight

According to scholars [13], the following steps are adopted to determine the criteria weight.

Step1: Construct the pair wise comparison matrices. After building the model hierarchy, it is suggested to construct the pair wise comparison matrices for criteria by using the fuzzy linguistic variables. The linguistic variables used in the present study are expressed in triangular fuzzy number and summarized in Table 1.

Step 2: Determine the fuzzy linguistic preference relation decision matrices. As recommended by [10], in case, the pair wise comparisons matrices obtained, have values included in the interval $[-c, 1+c]$ rather than in the interval $[0,1]$, the judgments values should be transformed by using the transformation function written above to preserve the reciprocity and additive consistency.

Step3: Aggregate the judgment matrices. Based on the work of [12], the individual evaluation of $\mathrm{m}$ decision makers are aggregated using the average value method described below.

$$
p_{i j}=\left(\frac{1}{m}\right) \otimes\left(p_{i j}^{1} \otimes p_{i j}^{2} \otimes \cdots \otimes p_{i j}^{m}\right)
$$

In order to estimate the criteria weight, scholars [13] propose to use the equation written below.

Table 1. Fuzzy linguistic assessment variables.

\begin{tabular}{cc}
\hline Linguistic variables & Triangular fuzzy numbers \\
\hline Absolutely important (AB) & $(0.90,1.00,1.00)$ \\
Very Strongly important (VS) & $(0.80,0.90,1.00)$ \\
Essentially important (ES) & $(0.50,0.70,0.90)$ \\
Weakly important (WK) & $(0.50,0.60,0.70)$ \\
Equally important (EI) & $(0.40,0.50,0.60)$ \\
Weakly not important (WN) & $(0.30,0.40,0.50)$ \\
Essentially not important (EN) & $(0.10,0.30,0.50)$ \\
Very strongly not important (VN) & $(0.00,0.10,0.20)$ \\
Absolutely not important (AN) & $(0.00,0.00,0.10)$ \\
\hline
\end{tabular}

Source: [12]. 


$$
\tilde{w}_{i}=\frac{\tilde{g}_{i}}{\tilde{g}_{1} \oplus \cdots \oplus \tilde{g}_{n}},
$$

where $g_{i}$ is the mean of the comparison values of row $i$ and is computed as follows:

$$
\tilde{g}_{i}=\frac{1}{n}\left[\tilde{p}_{i 1} \oplus \tilde{p}_{i 2} \oplus \cdots \oplus \tilde{p}_{i n}\right], \quad i=1, \cdots, n .
$$

Finally, the fuzzy weight obtained in Equation (4) is defuzzified using fuzzy mean method presented below:

$$
w_{i}=\frac{w_{i}^{l}+w_{i}^{m}+w_{i}^{u}}{3}
$$

\subsection{Fuzzy Quantified SWOT Framework}

It is worth mentioning that since the integrated method has been constructed by introducing the concept of multi-criteria decision making method into SWOT analysis, the technique include therefore the four components of a decision-making process namely criteria, alternatives, performances and weights. Criteria are defined as SWOT factors that are the internal and external factors; alternatives refer to objects compared; performances are the values of the objects compared with regards to all the key factors; and finally weights are the relative measurements of criteria. Within the integrated method, the steps of fuzzy linguistic preference relation proposed by [13] are followed to determine the weights of the internal and external criteria. The integrated approach consists of the following steps outlined below:

Step 1: Select alternatives ports in competition.

Step 2: Identify the key criteria of internal and external assessment to be used in the model.

Step 3: Build a hierarchical structure to assess the ports regarding their internal and external criteria and construct the pair wise comparison matrices based on fuzzy linguistic preference relations framework.

Step 4: Survey experts to evaluate the weights of key factors.

Step 5: Aggregate the individual evaluation of the decision makers.

Step 6: Estimate the internal and external criteria weights.

Step 7: Collect performance data.

Step 8: Normalize the performance values. The performance values should be transformed into dimensionless units and the criteria compared to each other. According to the same authors, the following normalization formula has been applied:

1) Benefit criteria normalization (the higher the better)

$$
r_{i j}=\frac{p_{i j}}{\max _{j}\left(p_{i j}\right)}, \forall j
$$

2) Cost-criteria normalization (the lower the better)

$$
r_{i j}=\frac{\min _{i j}\left(p_{i j}\right)}{p_{i j}}, \forall j
$$


3) Moderation criteria normalization (the more moderate the better)

$$
r_{i j}=\frac{\min \left\{p_{i j}, p_{0}\right\}}{\max \left\{p_{i j}, p_{0}\right\}} \text {, where } p_{0}=\frac{1}{n} \sum_{j=1}^{n} p_{i j}
$$

where $p_{i j}$ and $r_{i j}$ respectively denote the non-normalized and normalized performance value of the jth alternative of the ith criterion and for $r_{i j}, 0 \leq r_{i j} \leq 1$.

Step 9: Determine the internal and external weighted score $R_{J}^{I}$ and $R_{J}^{E}$ of each port which is computed by using the criteria weight obtained under fuzzy linguistic preference relation and the normalized performance values. The equations are expressed as follows

$$
\begin{array}{r}
R_{j}^{I}=\sum_{i=1}^{m_{1}}\left(w_{i}^{I} \times r_{i j}^{I}\right), \quad j=1,2, \cdots, n \\
R_{j}^{E}=\sum_{i=1}^{m_{1}}\left(w_{i}^{E} \times r_{i j}^{E}\right), \quad j=1,2, \cdots, n
\end{array}
$$

where $w_{i}^{I}$ is the weight of the ith internal factor $\left(i=1,2, \cdots, m_{1}\right)$ and $w_{i}^{E}$ is the weight of the ith external factor $\left(i=1,2, \cdots, m_{2}\right)$.

Step 10: Calculate the internal and external benchmark values to serve as references in the comparison of port internal and external competitive performance. The benchmarks values can be estimated by applying the mean of the alternatives weighted score method or take the benchmarking objective as reference value. The current study adopted the mean method. Accordingly, the internal benchmark values (IB) and external benchmark value (EB) are calculated based on Equation (12) and Equation (13) respectively.

$$
\begin{gathered}
I B=\frac{R_{1}^{I}+R_{2}^{I}+\cdots+R_{n}^{I}}{n} \\
E B=\frac{R_{1}^{E}+R_{2}^{E}+\cdots+R_{n}^{E}}{n}
\end{gathered}
$$

Step 11: Calculate and compare the internal coordinate value $\left(I C_{j}\right)$ and the external coordinate value $\left(E C_{j}\right)$ such as:

$$
\begin{gathered}
I C_{j}=R_{j}^{i}-A I, j=1,2, \cdots, n \text { and }-1 \leq I C \leq+1 \\
E C_{j}=R_{j}^{i}-A E, j=1,2, \cdots, n \text { and }-1 \leq E C \leq+1
\end{gathered}
$$

Step 12: Set the ports on the four quadrants in the SWOT-GSM matrix to identify their competitive positions.

At this stage, the sampled ports are placed altogether in the four quadrants of the coordinate according to their internal and external condition with the ordinate referring to the external environment and the abscissa defining the internal environment. The strategies to be proposed in the grand strategy matrix regarding the position in the quadrant are explained in Appendix 1.

\subsection{Variables Selection and Data Collection}

The internal and external factors were selected based on the review of the literature and 
used for the purpose of this study. A survey questionnaire based fuzzy preference linguistics relation was constructed to evaluate the weight of the variables selected. The choice of the questionnaire participants was based on non-probability sampling, especially expert sampling. In fact, expert sampling consist of targeting a sample of persons with known or demonstrable experience and expertise in some area [26]. The literature has highlighted the major role played by shipping lines in making the decisions to select a specific port [15]. Moreover, within a shipping company, the decision to select a specific port is made by one or few senior officials, thus in this context, the non-probability sampling is selected. Major shipping lines calling at the ports studied were therefore invited to evaluate the relative importance of these factors regarding their decision to select a particular port in the sub-region. Due to the limited performance data availability, the factors were refined and selected in order to obtain the key attributes affecting shipping lines perception in their decision to choose a port in West Africa. The factors used in the internal evaluation are namely water depth, crane productivity, ship turnaround time, quay length, volume handled, dwell time, terminal area and handling cost while those utilized in the external evaluation are efficiency of custom service, political risk, and significance in the international shipping network, economy performance, proximity to hinterland and level of corruption. Data collection was implemented via google forms. The performances data related to the internal factors were obtained from official websites of the container ports and West and Central Africa port authorities association over the period 2010 and 2013. The performance data related to external factors are collected from World Development Indicator database for the years 2010 and 2013 respectively, except data related to political risk obtained from [27] [28]. The gross domestic product (GDP) is used as a proxy for the economic performance of port host country. Custom efficiency score is used as proxy for the efficiency of custom service to reflect the efficacy of government regulation and policies regarding custom sector. Liner shipping connectivity index is used to proxy the significance of port host country in the international shipping network. Country corruption perception index is used as proxy for Level of corruption. A hierarchical structure of the evaluation of port internal and external condition was constructed and described in Figure 1.

\section{Empirical Analysis}

Considering the purpose of this study, the container terminals were selected with the aim to include those comparable to Abidjan and reflecting best performances in terms of throughput in West Africa sub-region. Accordingly, the sample size is limited to Abidjan container port and its main competitors in West Africa namely Tema, Cotonou, Lome, Dakar and Lagos. A quantified SWOT approach which integrates Fuzzy linguistic preference relations is adopted to assess the competitive position of these ports.

\subsection{Evaluation of Criteria Weight}

Out of 12 questionnaires sent, 7 (58.33\%) valid responses were received for pair wise comparison matrices construction. Statements (1) and (2) were used to generate the 


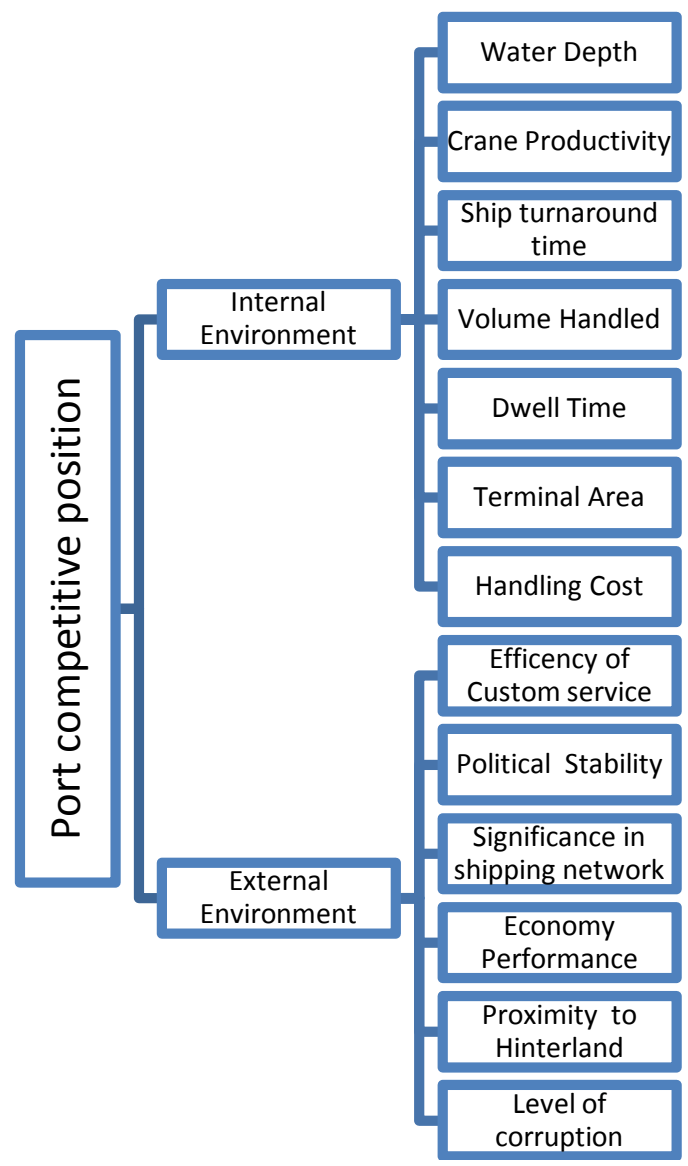

Figure 1. Model hierarchy.

additive and consistent fuzzy pair wise comparison matrices. The additive and consistent judgment matrices of all the evaluators were aggregated with respect to internal and external environment using Equation (3). The fuzzy weight criteria and the defuzzified weight are obtained according to Equation (4) and Equation (6) respectively. According to [5], It is assumed that the internal and external environment have the same weight in the hierarchy that is one. Considering the internal factors assessment, the results reveal that among all criteria, crane productivity and ship turnaround time followed by water depth respectively are the most important criteria influencing the perception of shipping lines calling at West African port and thus affecting port competitiveness in the region. The results can be seen in Table 2 .

Besides, the internal factors evaluation, the results from the external factors analysis show that port host country political risk greatly affects shipping lines decision in choosing a specific port in West Africa. These results confirm the findings of the empirical research conducted by researchers [22] on West African ports attractiveness. Moreover, the respondents highlighted the importance of the region economy performance as well as port proximity to hinterland. In fact, with the poor conditions of roads network and the few railway dating back to the colonial period in the region, it is advantageous to select port close to the hinterland in order to reduce total cost in terms of 
time, security and distance. The results can be seen in Table 3.

\subsection{Determination of Port Competitive Position}

The scales and direction of criteria have been unified by normalizing the performance values for the year 2013. The weighted scores computed can be seen in Table 4. The benchmarks and the coordinates values calculated for each container terminal are summarized in Table 5. It can be seen that Abidjan has the best internal coordinate value of 0.1329 , followed by Lagos (0.0272), Dakar (0.0176), Tema (-0.0624), Lome (0.0034) and Cotonou (-0.1186) respectively. This means that Abidjan had a substantial internal strength in comparison to its competitors and Cotonou had a critical internal weakness. Considering the external environment, Tema had the best external coordinate value of (0.1257), followed by Abidjan (0.0746), Lome (0.0389), Cotonou $(-0.0211)$, Lagos $(-0.1049)$ and Dakar $(-0.1133)$ respectively.

The results imply that compared to Abidjan and the four others port, Tema enjoyed the best opportunities for development. In order to identify the competitive position of the ports, their coordinate values are plotted in the quadrant of the grand strategy matrix as described in Figure 2. The analysis of Figure 2 reveals that Abidjan with its substantial

Table 2. Internal factor weight.

\begin{tabular}{cccc}
\hline & Internal (I) Criteria & Fuzzy Weight & Defuzzified Weight \\
\hline I1 & Water depth & $(0.1399,0.1464,0.1537)$ & 0.1467 \\
I2 & Crane productivity & $(0.1478,0.1554,0.1634)$ & 0.1553 \\
I3 & Ship Turnaround time & $(0.1496,0.1563,0.1639)$ & 0.1567 \\
I4 & Quay Length & $(0.1263,0.1325,0.1394)$ & 0.1323 \\
I5 & Volume handled & $(0.0961,0.102,0.108)$ & 0.102 \\
I6 & Dwell time & $(0.0943,0.0998,0.1053)$ & 0.0997 \\
I7 & Terminal area & $(0.0811,0.0867,0.0914)$ & 0.0863 \\
I8 & Handling cost & $(0.1149,0.1208,0.1274)$ & 0.121 \\
& & & 1 \\
\hline
\end{tabular}

Table 3. External factor weight.

\begin{tabular}{lccc}
\hline & External (E) Criteria & Fuzzy Weight & Defuzzified Weight \\
\hline E1 & Efficiency of Custom service & $(0.1389,0.1429,0.1718)$ & 0.1512 \\
E2 & Political risk & $(0.2331,0.2413,0.278)$ & 0.2508 \\
E3 & Significance in the international shipping network & $(0.1067,0.1432,0.1593)$ & 0.1364 \\
E4 & Economy performance & $(0.1445,0.1815,0.2122)$ & 0.1794 \\
E5 & Proximity to hinterland & $(0.1333,0.1606,0.1858)$ & 0.1599 \\
E6 & Level of corruption & $(0.1054,0.12,0.1415)$ & 0.1223 \\
& Sum & & 1 \\
\hline
\end{tabular}


Table 4. Assessment of weighted average scores of container terminals.

\begin{tabular}{cccccccc}
\hline \multirow{2}{*}{ Criteria } & Defuzzified weight & \multicolumn{7}{c}{ Container terminals } \\
\cline { 3 - 7 } & & Abidjan & Tema & Lome & Cotonou & Lagos & Dakar \\
\hline I1 & 0.1467 & 0.1467 & 0.135 & 0.1408 & 0.1174 & 0.1056 & 0.135 \\
I2 & 0.1553 & 0.1398 & 0.1553 & 0.1398 & 0.1398 & 0.1165 & 0.1553 \\
I3 & 0.1567 & 0.1567 & 0.0049 & 0.1567 & 0.0065 & 0.0131 & 0.0065 \\
I4 & 0.1323 & 0.1316 & 0.0756 & 0.0566 & 0.0711 & 0.1323 & 0.0869 \\
I5 & 0.102 & 0.0406 & 0.0558 & 0.018 & 0.019 & 0.102 & 0.0283 \\
I6 & 0.0997 & 0.0582 & 0.0279 & 0.0537 & 0.0582 & 0.0166 & 0.0997 \\
I7 & 0.0863 & 0.0534 & 0.0377 & 0.0188 & 0.0314 & 0.0863 & 0.0549 \\
I8 & 0.121 & 0.0721 & 0.1116 & 0.0852 & 0.1042 & 0.121 & 0.1172 \\
Sum/Rj & 1 & 0.7991 & 0.6038 & 0.6696 & 0.5476 & 0.6934 & 0.6838 \\
E1 & 0.1512 & 0.1334 & 0.1271 & 0.1197 & 0.1512 & 0.1346 & 0.1495 \\
E2 & 0.2508 & 0.1759 & 0.2084 & 0.2508 & 0.111 & 0.0654 & 0.1693 \\
E3 & 0.1364 & 0.1121 & 0.1236 & 0.0943 & 0.0912 & 0.1364 & 0.0708 \\
E4 & 0.1794 & 0.1794 & 0.1423 & 0.0996 & 0.1339 & 0.105 & 0.0705 \\
E5 & 0.1599 & 0.1526 & 0.1599 & 0.1485 & 0.144 & 0.1373 & 0.091 \\
E6 & 0.1223 & 0.0791 & 0.1223 & 0.0839 & 0.1055 & 0.0743 & 0.0935 \\
Sum/Rj & $\mathbf{1}$ & $\mathbf{0 . 8 3 2 5}$ & $\mathbf{0 . 8 8 3 6}$ & $\mathbf{0 . 7 9 6 8}$ & $\mathbf{0 . 7 3 6 8}$ & $\mathbf{0 . 6 5 3}$ & $\mathbf{0 . 6 4 4 6}$ \\
\hline & & & & & &
\end{tabular}

Table 5. The benchmarks and coordinate values for the year 2013.

\begin{tabular}{cccccccc}
\hline Coordinate value & Abidjan & Tema & Lome & Cotonou & Lagos & Dakar & Benchmark value \\
\hline Weighted score (WS) & 0.7991 & 0.6038 & 0.6696 & 0.5476 & 0.6934 & 0.6838 & 0.6662 \\
Coordinate value (IC) & 0.1329 & -0.0624 & 0.0034 & -0.1186 & 0.0272 & 0.0176 & \\
Weighted score (WS) & 0.8325 & 0.8836 & 0.7968 & 0.7368 & 0.653 & 0.6446 & 0.7579 \\
Coordinate value (EC) & 0.0746 & 0.1257 & 0.0389 & -0.0211 & -0.1049 & -0.1133 & \\
\hline
\end{tabular}

internal strength and positive external environment is located in the first quadrant of the matrix, and thus has the best competitive position in comparison to its competitors. Tema and Lome are positioned in the second quadrant. In fact, both ports, particularly Tema with the significant opportunities offers by its environment, are limited in terms of internal resources. Compared to the port of Abidjan, Tema is limited in terms of yard space, storage area, handling equipment and capacity to transport the container to the hinterland. The results are in line with the report made in [29]. According to this report, Tema has reached its limit to accommodate trade traffic and the port is facing with increase congestion for mooring at the berths

The port of Cotonou found in the third quadrant has the weakest internal condition and poor external condition as well. In order to compete favorably, Cotonou has to improve its internal competitive strength and avoid the threats from its external environ- 
ment. Lagos and Dakar located in the fourth quadrant are facing critical threat from their environment, which undermines their competitive position.

\subsection{Examining the Changes in Terminal Competitive Position}

The environmental scan can be done several times to identify the changes in the competitive position of the ports. Accordingly, in order to observe the change in the competitive position of the ports and especially Abidjan, the analysis have been done a second time considering the performance values of the year 2010 and assuming the weight of the criteria constant. It is worth reminding that during that period, Cote d'Ivoire was experiencing a political conflict which had greatly affected its economic activities. The results relative to the benchmarks and coordinates values are summarized in Table 6. The analysis of the position of Abidjan indicates that it had enjoyed a

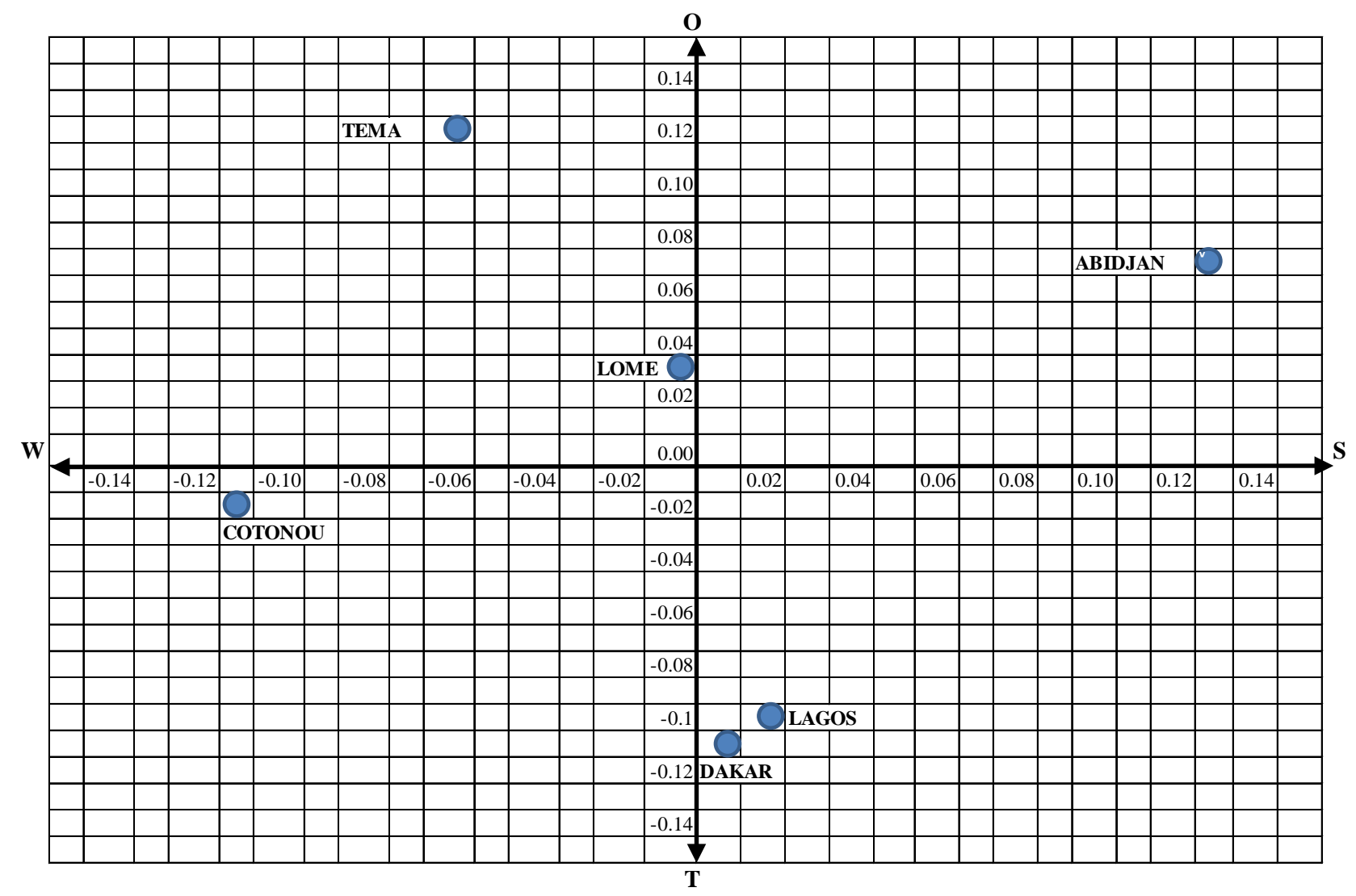

Figure 2. Port competitive position in combined SWOT-GSM matrix (2013).

Table 6. The benchmarks and coordinate values for the year 2010 .

\begin{tabular}{cccccccc}
\hline Coordinate value & Abidjan & Tema & Lome & Cotonou & Lagos & Dakar & Benchmark value \\
\hline Weighted score (WS) & 0.8065 & 0.6014 & 0.6823 & 0.5572 & 0.6934 & 0.6871 & 0.6713 \\
Coordinate value (IC) & 0.1352 & -0.0699 & 0.011 & -0.1141 & 0.0221 & 0.0158 & \\
Weighted score (WS) & 0.6126 & 0.8962 & 0.816 & 0.6119 & 0.7219 & 0.6929 & 0.7253 \\
Coordinate value (EC) & -0.1127 & 0.1709 & 0.0907 & -0.1134 & -0.0034 & -0.0324 & \\
\hline
\end{tabular}


competitive strength but in the meantime, was facing a significant threat undermining its ability to compete in the sub-region. This can be explained by the political instability In Cote d'Ivoire which led many operators to shift their activities in the neighboring ports. The competitive position of each port during the year 2010 and 2013 are summarized in Figure 3. The direction of the arrow indicates the evolution from 2010 to 2013. It can be seen that during the year 2010, none of the ports were located in the first quadrant. This means that all the ports were facing significant issues either in terms of limited strength or in terms of critical threat. For instance, Abidjan was located in the fourth quadrant due to the threat from the external environment. Considering the change in the competitive position from 2010 to 2013, the most significant change is the promotion of Abidjan from the fourth quadrant to the first quadrant resulting from an enhancement in the external environment. On the other hand, it can be seen that the port of Cotonou has improved its competitive position by an improvement of its external

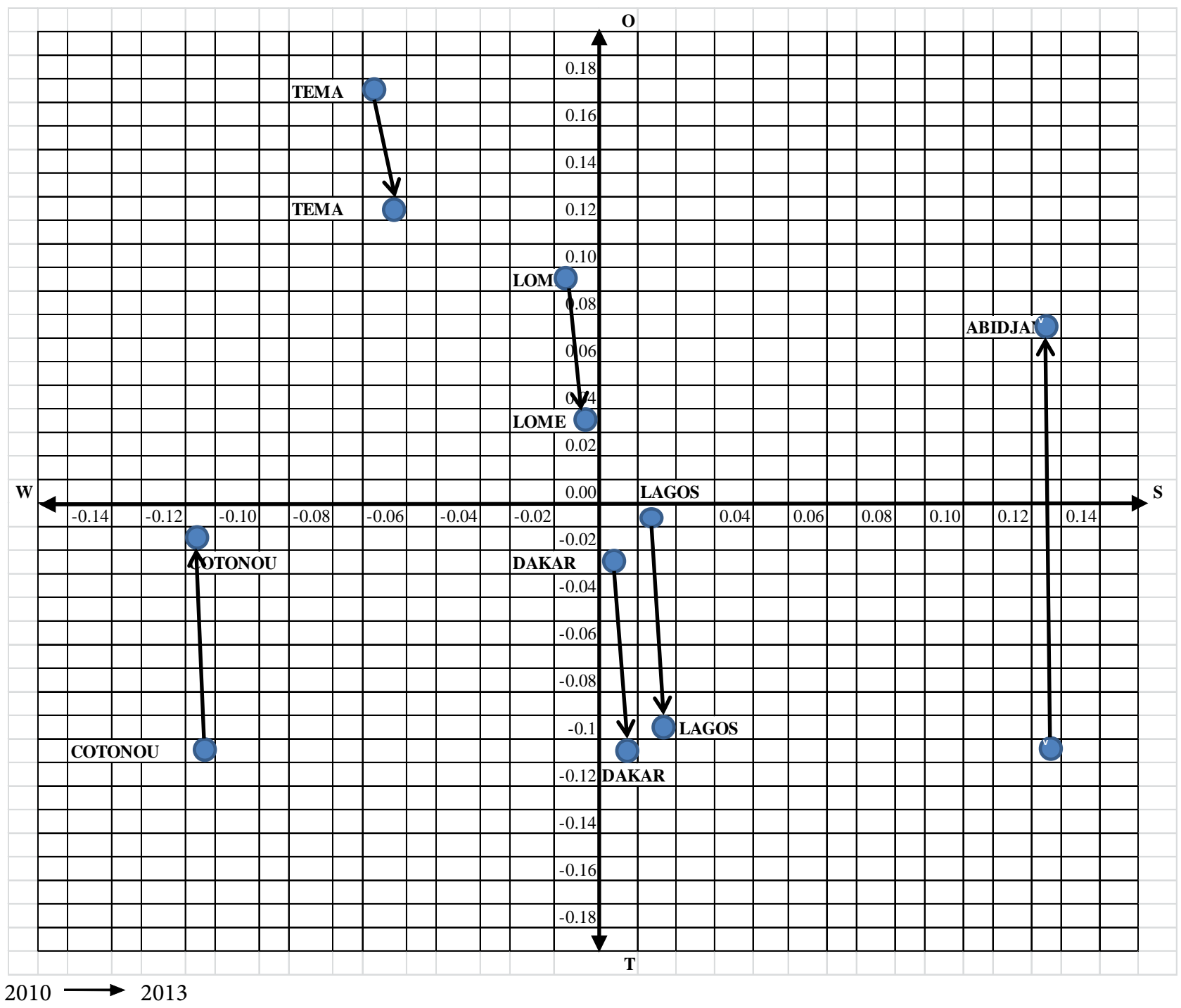

Figure 3. Port competitive position in combined SWOT-GSM matrix in 2010 and 2013. 
coordinated, reflecting a reduction of the threats in its environment. While Tema and Lome have experienced a slight increase in their internal strength, they were faced with a reduction of opportunities in their environment. Finally, the ports of Dakar and Lagos have declined in terms of competitive position resulting to an increase of threats in their environment.

\section{Conclusion}

This article adopts a quantified SWOT framework which integrates fuzzy linguistic preference relation to evaluate the competitive position of Abidjan container terminal in West Africa. The integration of fuzzy linguistic preference relation in the quantified SWOT framework circumvents the difficulties in terms of data collection and consistency of judgment matrices prevailing in the conventional AHP and Fuzzy AHP. On the other hand, the study provides relevant evidences about the key internal and external attributes shipping lines considered as important and hence the attributes that ports in the region most need to enhance in order to improve their attractiveness and competitive position in the sub-region. The findings indicate that West African port authorities and terminal operators could focus on improving ship turnaround time, crane productivity and physical infrastructure among the internal factors while government should assure political stability, economy performance but also improve transport infrastructure in order for the ports to achieve a competitive advantage. The change in port competitive position from 2010 to 2013, highlights that the difficulties of West African port in attracting customers in the sub-region are not only related to internal problems such as inadequate infrastructures and facilities or inefficiency, but significant constraint outside the ports constraints their competitiveness. Consequently, a suitable strategy fit between the internal strength and weaknesses, and external opportunities and threat may help the port to achieve a sustainable growth.

\section{References}

[1] Lee, S.W., Song, D.W. and Ducruet, C. (2008) A Tale of Asia's World Ports: The Spatial Evolution in Global Hub Port Cities. Geoforum, 39, 372-385. http://dx.doi.org/10.1016/j.geoforum.2007.07.010

[2] Panayides, P. and Song, D.-W. (2012) Determinants of Users' Port Choice. In: Talley, W.K., Ed., The Blackwell Companion to Maritime Economics, Wiley-Blackwell, Oxford, 599-622. http://dx.doi.org/10.1002/9781444345667.ch29

[3] Shariatmadari, M., Sarfaraz, A.H., Hedayat, P. and Vadoudi, K. (2013) Using SWOT Analysis and SEM to Prioritize Strategies in Foreign Exchange Market in Iran. Procedia-Social and Behavioral Sciences, 99, 886-892. http://dx.doi.org/10.1016/j.sbspro.2013.10.561

[4] Pur, M.M. and Tabriz, A.A. (2012) SWOT Analysis Using of Modified Fuzzy QFD: A Case Study for Strategy Formulation in Petrokaran Film Factory. Procedia-Social and Behavioral Sciences, 41, 322-333. http://dx.doi.org/10.1016/j.sbspro.2012.04.037

[5] Chang, H.H. and Huang, W.C. (2006) Application of a Quantification SWOT Analytical Method. Mathematical and Computer Modelling, 43, 158-169.

http://dx.doi.org/10.1016/j.mcm.2005.08.016 
[6] Saaty, R.W. (1987) The Analytic Hierarchy Process-What It Is and How It Is Used. Mathematical Modelling, 9, 161-176. http://dx.doi.org/10.1016/0270-0255(87)90473-8

[7] Kurttila, M., Pesonen, M., Kangas, J. and Kajanus, M. (2000) Utilizing the Analytic Hierarchy Process (AHP) in SWOT Analysis-A Hybrid Method and Its Application to a Forest-Certification Case. Forest Policy and Economics, 1, 41-52.

http://dx.doi.org/10.1016/S1389-9341(99)00004-0

[8] Lee, K.L. and Lin, S.C. (2008) A Fuzzy Quantified SWOT Procedure for Environmental Evaluation of an International Distribution Center. Information Sciences, 178, 531-549. http://dx.doi.org/10.1016/j.ins.2007.09.002

[9] Qu, L. and Chen, Y. (2009) An Integrated Fuzzy AHP-SWOT Method and Its Application in the Analysis of China's Software Industry Bases.

[10] Wang, T.C. and Chen, Y.H. (2008) Applying Fuzzy Linguistic Preference Relations to the Improvement of Consistency of Fuzzy AHP. Information Sciences, 178, 3755-3765.

http://dx.doi.org/10.1016/j.ins.2008.05.028

[11] Chen, Y.H., Wang, T.C. and Wu, C.Y. (2011) Multi-Criteria Decision Making with Fuzzy Linguistic Preference Relations. Applied Mathematical Modelling, 35, 1322-1330. http://dx.doi.org/10.1016/j.apm.2010.09.009

[12] Lu, S.T., Yu, S.H., Chang, D.S. and Su, S.C. (2013) Using the Fuzzy Linguistic Preference Relation Approach for Assessing the Importance of Risk Factors in a Software Development Project. Mathematical Problems in Engineering, 2013, Article ID: 376375. http://dx.doi.org/10.1155/2013/376375

[13] Rezaei, J. and Ortt, R. (2013) Multi-Criteria Supplier Segmentation Using a Fuzzy Preference Relation Based AHP. European Journal of Operational Research, 225, 75-84. http://dx.doi.org/10.1016/j.ejor.2012.09.037

[14] Herrera-Viedma, E., Herrera, F., Chiclana, F. and Luque, M. (2004) Some Issues on Consistency of Fuzzy Preference Relations. European Journal of Operational Research, 154, 98109. http://dx.doi.org/10.1016/S0377-2217(02)00725-7

[15] Aronietis, R., Markianidou, P., Meersman, H., Pauwels, T., Pirenne, M., Van de Voorde, E., et al. (2010) Some Effects of Hinterland Infrastructure Pricing on Port Competitiveness: Case of Antwerp. 12th WCTR, Lisbon, 11-15 July 2010, 1-23.

[16] Wiegmans, B.W., Hoest, A.V.D. and Notteboom, T.E. (2008) Port and Terminal Selection by Deep-Sea Container Operators. Maritime Policy \& Management, 35, 517-534. http://dx.doi.org/10.1080/03088830802469329

[17] Park, N.K. and Suh, S.C. (2013) An Empirical Research on Container Terminal Selection Criteria and the Relationship with Shipping Company's Satisfaction: The Case of Korea. Journal of Contemporary Management, 41-53.

[18] Yeo, G.T., Roe, M. and Dinwoodie, J. (2008) Evaluating the Competitiveness of Container ports in Korea and China. Transportation Research Part A: Policy and Practice, 42, 910 921. http://dx.doi.org/10.1016/j.tra.2008.01.014

[19] Song, D.-W. and Panayides, P.M. (2008) Global Supply Chain and Port/Terminal: Integration and Competitiveness. Maritime Policy \& Management, 35, 73-87. http://dx.doi.org/10.1080/03088830701848953

[20] Chang, Y.-T., Lee, S.-Y. and Tongzon, J.L. (2008) Port Selection Factors by Shipping Lines: Different Perspectives between Trunk Liners and Feeder Service Providers. Marine Policy, 32, 877-885. http://dx.doi.org/10.1016/j.marpol.2008.01.003

[21] Yuen, C., Zhang, A.A. and Cheung, W. (2012) Port Competitiveness from the Users' Perspective: An Analysis of Major Container Ports in China and Its Neighboring Countries. 
Research in Transportation Economics, 35, 34-40.

http://dx.doi.org/10.1016/j.retrec.2011.11.005

[22] Gohomene, D.A., Yang, Z., Bonsal, S., Maistralis, E., Wang, J. and Li, K.X. (2015) The Attractiveness of Ports in West Africa: Some Lessons from Shipping Lines' Port Selection. Growth and Change, 47, 416-426. http://dx.doi.org/10.1111/grow.12133

[23] Notteboom, T. (2011) An Application of Multi-Criteria Analysis to the Location of a Container Hub Port in South Africa. Maritime Policy \& Management, 38, 51-79. http://dx.doi.org/10.1080/03088839.2010.533710

[24] Medda, F. and Caschili, S. (2015) The Port Attractiveness Index: Application on African Ports. Region et Developpement, 41, 47-82.

[25] Hyuksoo, C.H.O. and Sangkyun, K.I.M. (2015) Examining Container Port Resources and Environments to Enhance Competitiveness: A Cross-Country Study from Resource-Based and Institutional Perspectives. The Asian Journal of Shipping and Logistics, 31, 341-362. http://dx.doi.org/10.1016/j.ajsl.2015.09.002

[26] Trochim, W., Donnelly, J.P. and Arora, K. (2015) Research Methods: The Essential Knowledge Base. Nelson Education, Cengage Learning, Boston.

[27] Hewitt, J.J., Wilkenfeld, J. and Gurr, T.R. (2010) Peace and Conflict 2010 Executive Summary. University of Maryland, College Park.

[28] Hewitt, J. J., Wilkenfeld, J. and Gurr, T. R. (2012) Peace and Conflict 2012 Executive Summary. University of Maryland, College Park.

[29] MLTC/CATRAM (2013) Market Study on Container Terminals in West and Central Africa. 


\section{Appendix 1: Strategy Related to the Competitive Position in GSM}

\begin{tabular}{ll}
\hline Quadrant $\begin{array}{l}\text { Competitive Position } \\
\text { 1) }\end{array}$ & $\begin{array}{l}\text { Sirms positioned in this quadrant can use their strengths to adopt } \\
\text { strategies, such as market penetration, market development, and } \\
\text { product development, to form competitive strength. If a particular firm } \\
\text { in the first quadrant has extra resources, forward, backward and }\end{array}$ \\
horizontal integration may be efficient strategies.
\end{tabular}

Submit or recommend next manuscript to SCIRP and we will provide best service for you:

Accepting pre-submission inquiries through Email, Facebook, LinkedIn, Twitter, etc. A wide selection of journals (inclusive of 9 subjects, more than 200 journals)

Providing 24-hour high-quality service

User-friendly online submission system

Fair and swift peer-review system

Efficient typesetting and proofreading procedure

Display of the result of downloads and visits, as well as the number of cited articles

Maximum dissemination of your research work

Submit your manuscript at: http://papersubmission.scirp.org/

Or contact ojapps@scirp.org 